\title{
Penyuluhan dan Pelatihan Stimulasi Periode Emas Anak 1000 HPK di Wilayah Puskesmas Sipoholon, Kabupaten Tapanuli Utara
}

\author{
Sulastry Pakpahan \\ Poltekkes Medan \\ lastryp@gmail.com
}

\begin{abstract}
National data according to the Indonesian Ministry of Health in 2015, $11.5 \%$ of children under five in growth and development of abnormalities. Knowledge and awareness of the importance of stimulation of growth and development during the $1000 \mathrm{HPK}$ period is needed so that parents can take advantage of this period to form children who have intellectual, emotional, language, creative and positive character. Activities carried out by providing counseling to pregnant women, mothers or husbands with toddlers and training to health cadres. The implementation of the activity lasts 3 days, divided into 2 stages, namely day 1-2 is the implementation of health education and day 3 is the implementation of training. The number of health education participants was 57 people and training participants were 48 people. Each participant was given a questionnaire to measure the increase in knowledge after the implementation of the activity. The results of this activity was obtained that the participants' knowledge increased by $24.56 \%$ in very good categories, $22.8 \%$ in good categories, and $43.38 \%$ in adequate categories. The increase in the knowledge of the training participants in the very good category increased by $27.1 \%$, the good category was $20.8 \%$ and the moderate category was $47.9 \%$. Health education and training about growth and development stimulation during the 1000 HPK period can increase knowledge and awareness of mothers, families and health cadres so they are expected to be able to apply the knowledge received during the training in everyday life and to the surrounding community.
\end{abstract}

Keywords: Growth, golden period, training

\section{Pendahuluan}

Tumbuh kembang anak di Indonesia masih perlu mendapatkan perhatian serius, Angka keterlambatan pertumbuhan dan perkembangan masih cukup tinggi yaitu sekitar 5-10\% mengalami keterlambatan perkembangan umum. Dua dari 1.000 bayi mengalami gangguan perkembangan motorik dan 3 sampai 6 dari 1.000 bayi juga mengalami gangguan pendengaran serta satu dari 100 anak mempunyai kecerdasan kurang dan keterlambatan bicara. (Sugeng et al., 2019). Periode The Golden Age dalam kehidupan manusia merupakan periode yang paling krusial terutama bagi setiap anak. Golden age atau periode emas adalah tahapan pertumbuhan dan perkembangan yang paling penting pada masa awal kehidupan anak. Golden age meliputi 1000 hari pertama kehidupan anak yang dihitung dari masa dalam kandungan sampai dengan usia anak mencapai dua tahun. Golden age period adalah masa-masa dimana otak anak berkembang sangat pesat dan paling cepat dalam menyerap informasi. (Patria, 2017)

Dari berbagai penelitian diketahui bahwa the Golden Age merupakan masa yang sangat efektif dan urgen untuk dilakukannya optimalisasi berbagai potensi kecerdasan yang dimiliki oleh anak manusia untuk menuju Sumber Daya Manusia yang berkualitas. Keberhasilan ataupun kegagalan pengembangan kecerdasan intelektual, emosional dan spiritual seorang anak sering terletak pada tingkat kemampuan dan kesadaran orang tua dalam memanfaatkan peluang pada masa keemasan ini.(Uce, 2014)

Otak janin mengalami periode pertumbuhan cepat (brain growth spurt) pertama kali pada saat kehamilan trimester ketiga. Pada trimester ketiga ini, sel neuron (sel-sel otak) pada otak besar 
membelah dan membagi dengan cepat. Masa pertumbuhan emas otak (brain growth spurt) tahapan kedua terjadi saat bayi baru lahir sampai usia 3 tahun. Usia bayi 0-6 bulan sangat disarankan untuk diberikan ASI eksklusif. ASI mengandung nutrisi yang cukup hingga bayi berusia 6 bulan. Menginjak usia 6 bulan sampai 3 tahun bayi mulai diberi makanan sesuai kebutuhan tubuhnya. Asupan zat gizi adalah faktor utama yang berperan meningkatkan kecerdasan otak secara optimal. Jika pada masa ini bayi tidak mendapatkan kebutuhan gizinya, kekurangannya tak akan bisa dipenuhi lagi di kemudian hari. Karena itu, penting untuk bisa memenuhi kebutuhan nutrisi seimbang di usia ini. (Uce, 2014)

Menurut UNICEF tahun 2011 didapatkan data tingginya angka kejadian gangguan pertumbuhan dan perkembangan anak usia balita khususnya gangguan perkembangan motorik didapatkan sebesar $27,5 \%$ atau 3 juta anak mengalami gangguan.(Unicef, 2011) Data nasional menurut Kementrian Kesehatan Indonesia tahun 2015, terhitung sebesar 11,5\% anak balita di Indonesia mengalami kelainan pertumbuhan dan perkembangan (Kemenkes, 2016). Stimulasi adalah rangsangan yang datang dari lingkungan luar anak. Stimulasi merupakan hal yang sangat penting dalam tumbuh kembang anak. Anak yang mendapat stimulasi yang tearah akan lebih cepat berkembang dibandingkan dengan anak yang kurang atau bahkan tidak mendapat stimulasi. (Soetjiningsih, 2014) Setiap bayi yang lahir memiliki 100 milyar sel otak. Namun meski setiap bayi memiliki jumlah sel otak yang sama, optimalisasi penggunaan otak belum tentu sama pada setiap anak. Pasalnya belum semua sel-sel otak bayi saling terhubung dengan sempurna. Padahal semakin kuat hubungan antar sel, semakin kuat pula daya tangkap dan memori anak. Jumlah hubungan antar sel saraf tersebut menjadi dasar untuk memori pada manusia.

Berdasarkan kajian neurologi dan psikologi perkembangan, kualitas anak dini usia disamping dipengaruhi oleh faktor bawaan (nature) juga sangat dipengaruhi oleh faktor kesehatan, gizi, dan psikososial yang diperoleh dari lingkungannya. Adapun pemanfaatan kesempatan ini tidak lepas dari aspek-aspek pembinaan kecerdasan intelektual, kecerdasan emosi, kecerdasan berbahasa, kecerdasan kreatifitas dan yang terpenting adalah kecerdasan spiritual.(Uce, 2014) Mengingat periode 2 tahun pertama ini merupakan masa yang "relatif pendek" dan tidak akan terulang kembali , maka orang tua dan keluarga harus memanfaatkan periode yang singkat ini untuk membentuk anak kearah yang positif dengan cara memberikan masukan /pembelajaran nilai nilai positif, memberikan asupan nutrisi dan gizi seimbang, memberikan stimulasi yang tepat serta memberikan pelayanan kesehatan yang terbaik bagi balita.(Kemenkes, 2018a)

Usaha yang dapat dilakukan mencakup pemeliharaan aspek kesehatan, pemberian nutrisi, stimulasi intelektual, penyediaan kesempatan-kesempatan yang luas bagi anak untuk mengeksplorasi dan belajar secara aktif, pengembangan sosial dan emosional, serta memberikan pengasuhan dan bimbingan kepada anak agar mampu memahami potensi diri yang dimilikinya. Semua pembinaan ini dilakukan dengan pembiasaan pola hidup yang baik yang dilakukan secara teratur, berulang-ulang, bertahap sesuai dengan pertumbuhan dan perkembangan anak, berkesinambungan, serta terpadu dengan berbagai pendekatan. Jika orang tua mengetahui betapa pentingnya periode emas tersebut untuk perkembangan otak anak secara optimal maka orang tua pasti ingin memberikan yang terbaik untuk anak-anaknya, karena mempunyai anak yang cerdas adalah dambaan setiap orang tua apalagi anak yang berguna bagi nusa dan bangsa.

Kegiatan ini bertujuan untuk mendukung peningkatan pengetahuan dan keterampilan ibu hamil, ibu menyusui, keluarga yang memiliki anak usia di bawah 2 tahun serta kader kesehatan dalam melakukan stimulasi pertumbuhan dan perkembangan pada masa 1000 hari pertama 
kehidupan (HPK) di wilayah kerja Puskesmas Sipoholon, Kabupaten Tapanuli Utara.

\section{Tinjauan Pustaka}

\subsection{Pertumbuhan dan perkembangan anak pada masa periode emas}

Pertumbuhan dan perkembangan mengalami peningkatan yang pesat pada usia dini, yaitu sejak kehamilan sampai usia 2 tahun yang disebut 1000 Hari Pertama Kebidupan. Masa ini sering juga disebut sebagai fase periode emas atau Golden Age.. Golden age merupakan masa yang sangat penting untuk memperhatikan tumbuh kembang anak secara cermat agar sedini mungkin dapat terdeteksi apabila terjadi kelainan. Selain itu, penanganan kelainan yang sesuai pada masa golden age dapat meminimalisasi disfungsi tumbuh kembang anak sehingga mencegah terjadinya disfungsi permanen. (Kemenkes, 2018a)

Pemantauan tumbuh kembang anak meliputi pemantauan dari aspek fisik, psikologi, dan sosial. Sedini mungkin pemantauan dapat dilakukan oleh orang tua. Istilah tumbuh kembang terdiri atas dua peristiwa yang sifatnya berbeda tetapi saling berkaitan dan sulit untuk dipisahkan, yaitu pertumbuhan dan perkembangan. Pertumbuhan (growth) berkaitan dengan masalah perubahan ukuran, besar, jumlah atau dimensi pada tingkat sel, organ maupun individu yang diukur dengan satuan berat (gram, kilogram), satuan panjang $(\mathrm{cm}, \mathrm{m})$, umur tulang, dan keseimbangan metabolik (retensi kalsium dan nitrogen dalam tubuh) sedangkan perkembangan merupakan pertambahan kemampuan struktur dan fungsi tubuh yang lebih kompleks, menyangkut adanya proses diferensiasi selsel, jaringan, organ, dan sistem organ yang berkembang sedemikian rupa sehingga masing-masing dapat memenuhi fungsinya (Soetjiningsih, 2014).

Proses perkembangan terjadi secara simultan dengan pertumbuhan, sehingga setiap pertumbuhan disertai dengan perubahan fungsi. Perkembangan merupakan hasil interaksi kematangan susunan saraf pusat dengan organ yang dipengaruhinya. Perkembangan fase awal meliputi beberapa aspek kemampuan fungsional, yaitu kognitif, motorik, emosi, sosial, dan bahasa. Perkembangan pada fase awal ini akan menentukan perkembangan fase selanjutnya. Kekurangan pada salah satu aspek perkembangan dapat mempengaruhi aspek lainnya.

Pertumbuhan dan perkembangan anak dipengaruhi oleh pertumbuhan otak, Pertumbuhan otak pada usia dini sangat mempengaruhi tumbuh kembang anak. Stimulasi yang diberikan sejak dini akan mempengaruhi perkembangan otak. Otak akan semakin berkembang apabila stimulasi yang diberikan semakin banyak. Anak perlu mendapat lingkungan yang merangsang pertumbuhan otak dan selalu mendapatkan stimulasi psikososial. Stimulasi tersebut dapat berupa kehangatan dan cinta tulus yang diberikan orang tua. Selain itu, orang tua dapat memberikan pengalaman langsung dengan menggunakan panca inderanya (penglihatan, pendengaran, perasa, peraba, dan penciuman). Interaksi anak dan orang tua melalui sentuhan, pelukan, senyuman, nyanyian, dan mendengarkan dengan penuh perhatian juga merupakan bentuk stimulasi secara dini. Ketika anak yang belum dapat berbicara mengoceh, ocehan itu perlu mendapatkan tanggapan sebagai bentuk stimulasi kemampuan bicara anak. Sejak dini orang tua semestinya mengajak bercakap-cakap dengan suara lembut dan memberikan rasa aman kepada anak.

Stimulasi sosial secara mudah dapat diberikan dengan cara sentuhan dan mengajak anak bermain. Apabila hal tersebut tidak diperoleh anak, maka anak dapat mengalami berbagai penyimpangan perilaku. Contoh penyimpangan perilaku adalah hilangnya citra diri, rendah diri, penakut, tidak mandiri atau sebaliknya anak menjadi agresif dan tidak mempunyai rasa malu. (Kemenkes, 2018b). Pemenuhan gizi yang baik sangat berperan dalam pencapaian 
pertumbuhan badan yang optimal, termasuk di dalamnya pertumbuhan otak anak. Makanan yang disediakan untuk anak sebaiknya memenuhi kecukupan energi dan semua zat gizi yang meliputi karbohidrat, protein, vitamin, mineral, dan lemak. Susunan hidangan disesuaikan dengan selera dan pola makan anak sehingga dapat meningkatkan nafsu makannya. Porsi makanan diberikan sesuai kebutuhan dan makanan dihidangkan dalam keadaan higienis. Derajat kesehatan dan gizi yang buruk juga akan menghambat pertumbuhan otak. Akibatnya hal ini akan menurunkan kemampuan otak dalam mencatat, menyerap, menyimpan, memproduksi, dan merekonstruksi informasi. Selain itu, masalah ini juga dapat menyebabkan gangguan pada pertumbuhan fisik. (Patria, 2017).

\subsection{Stimulasi Perkembangan Anak}

Stimulasi merupakan kegiatan yang dilakukan untuk merangsang kemampuan dasar anak agar dapat bertumbuh dan berkembang secara optimal. Stimulasi ini dapat dilakukan secara rutin dan sedini mungkin, yang diberikan oleh setiap orang yang berinteraksi dengan anak, mulai dari orang tua, pengasuh anak, anggota keluarga lain dan kelompok masyarakat di lingkungan rumah tangga. Apabila stimulasi kurang diberikan pada anak makan dapat menyebabkan penyimpangan atau gangguan tumbuh kembang.

Parameter yang dipakai untuk mengukur kemampuan dasar anak meliputi motorik kasar, motorik halus, kemampuan bicara atau bahasa, kemampuan sosialisasi dan kemandirian. Kemampuan melakukan gerak dan sikap tubuh yang melibatkan otot besar seperti duduk, berdiri dan sebagainya disebut dengan gerak motorik kasar. Gerak motorik halus adalah gerakan yang melibatkan bagian tubuh tertentu dengan melibatkan otot kecil seperti mengamati sesuatu, menulis, memegang dan sebagainya. Sedangkan kemampuan berbicara dan bahasa yaitu kemampuan memberikan respon terhadap suara, mengikuti perintah dan sebagainya. (Soetjiningsih, 2014)

Prinsip yang perlu diperhatikan dalam memberikan stimulasi adalah stimulasi dilakukan dengan kasih sayang, sesuai dengan kelompok anak, menyenangkan, tanpa paksaan dan tidak ada hukuman. Selain itu stimulasi dapat dilakukan dengan menggunakan alat bantu ataupun permainan (APE) sederhana dan aman untuk anak. Buku bacaan anak juga penting karena akan menambha kemampuan berbahasa dan menambah wawasan terhadap lingkungannya. Untuk perkembangan motorik diperlukan stimulasi dengan bermain, latihan ataupun olahraga misalkan melempar/menangkap bola, melompat, main tali, naik sepeda, dan sebagainya. Beberapa contoh alat permainan balita untuk menstimulasi perkembangannya yaitu: motorik kasar: sepeda, mainan bola ditarik atau didorong; motorik halus: pensil, bola, balok; bahasa: buku bergambar, buku cerita, puzzle, lego, boneka, pensil warna; sosial: bermain dengan anak sebaya, orangtua dan sebagainya. (Kemenkes, 2018a)

\section{Metode}

Kegiatan dilaksanakan dengan metode edukasi, sosialisasi (penyuluhan) serta pelatihan kepada kader kesehatan, ibu hamil, ibu menyusui, dan keluarga yang memiliki anak usia 2 tahun. Materi yang diberikan terkait stimulasi tumbuh kembang pada periode emas yaitu sejak dalam kandungan sampai usia 2 tahun (1000 Hari Pertama Kehidupan) meliputi manfaat stimulasi tumbuh kembang anak, melakukan stimulasi sesuai dengan usia anak, serta mendeteksi dini gangguan tumbuh kembang anak. Untuk mengetahui peningkatan pengetahuan dan keterampilan peserta diberikan kuesioner sebelum dan sesudah pelaksanaan kegiatan (pre test dan post test), yang mana item pertanyaan pada kuesioner difokuskan pada tingkat pengetahuan, pemahaman dan penerapan stimulasi tumbuh kembang anak di masa 1000 hari pertama kehidupan. Kegiatan ini melibatkan Puskesmas Sipoholon, bidan desa, tokoh 
masyarakat, di wilayah Puskesmas Situmeang Habinsaran, Kecamatan Sipoholon.

\section{Hasil dan Pembahasan}

Kegiatan ini dilaksanakan di Puskemas Situmeang Habinsaran, Sipoholon, Kabupaten Tapanuli Utara. Penyuluhan berlangsung selama 2 hari (20,27 Mei 2019) dan pelatihan 1 hari yaitu pada tanggal 18 Juni 2018. Jumlah peserta penyuluhan pada hari 1 adalah 30 orang, hari ke-2 adalah 27 orang, sedangkan peserta pelatihan berjumlah 48 orang. Setelah pelaksanaan penyuluhan dan pelatihan dilakukan penilaian pengetahuan peserta yang diuraikan pada tabel berikut ini:

Tabel 1. Karakteristik Peserta Kegiatan

\begin{tabular}{|c|c|c|c|c|c|}
\hline \multicolumn{2}{|c|}{ Kategori } & \multicolumn{2}{|c|}{ Pelatihan } & \multicolumn{2}{|c|}{ Penyuluhan } \\
\hline & & $\mathrm{n}$ & $\%$ & $\mathrm{n}$ & $\%$ \\
\hline \multirow[t]{4}{*}{ Umur } & $<30$ tahun & 18 & 37,6 & 14 & 24,6 \\
\hline & 30-40 tahun & 21 & 43,6 & 35 & 61,4 \\
\hline & $>40$ tahun & 9 & 18,8 & 8 & 14,0 \\
\hline & Jumlah & 48 & 100 & 57 & 100 \\
\hline \multirow{3}{*}{$\begin{array}{l}\text { Jumlah anak usia } \\
\text { dibawah } 2 \text { tahun dalam } \\
\text { keluarga }\end{array}$} & $\leq 2$ orang & 37 & 77,1 & 38 & 33,3 \\
\hline & $>2$ orang & 11 & 22,9 & 19 & 66,7 \\
\hline & Jumlah & 48 & 100 & 57 & 100 \\
\hline \multirow[t]{4}{*}{ Pendidikan } & Dasar & 16 & 33,4 & 11 & 19,3 \\
\hline & Menengah & 22 & 45,8 & 37 & 64,9 \\
\hline & PT & 10 & 20,8 & 9 & 15,8 \\
\hline & Jumlah & 48 & 100 & 57 & 100 \\
\hline \multirow[t]{5}{*}{ Pekerjaan } & Petani & 22 & 45,8 & 31 & 54,4 \\
\hline & Wiraswasta & 14 & 29,2 & 15 & 26,3 \\
\hline & Pegawai swasta & 4 & 8,3 & 7 & 12,3 \\
\hline & ASN & 8 & 16,7 & 4 & 7,01 \\
\hline & Jumlah & 48 & 100 & 57 & 100 \\
\hline
\end{tabular}

Sumber: Pengabdian kepada masyarakat tahun 2019

Umur peserta sangat erat hubungannya dengan pengetahuan seseorang, semakin bertambah umur semakin banyak menerima informasi mengenai berbagai hal dari berbagai sumber maka semakin meningkat pula pengetahuannya. Berdasarkan umur pada tabel 1. peserta pelatihan dan penyuluhan paling banyak pada kategori umur 30-40 tahun $(43,6 \% ; 61,4 \%)$. Berdasarkan tingkat pendidikan peserta kegiatan ini paling banyak pada kategori pendidikan menengah (SMA) $(45,8 \% ; 64,9 \%)$. Pendidikan menentukan pola pikir dan wawasan seseorang, semakin tinggi pendidikan maka semakin tinggi pula pengetahuannya. Pekerjaan dapat menentukan status ekonomi suatu keluarga. Berdasarkan pekerjaan pada peserta kegiatan ini paling banyak 
dengan pekerjaan petani $(45,8 \% ; 54,4 \%)$. Status ekonomi akan mempengaruhi pemenuhan kebutuhan akan informasi dalam hal ini informasi terkait stimulasi tumbuh kembang anak pada masa periode emas.

Tabel 2. Perbedaan tingkat pengetahuan peserta sebelum dan setelah mengikuti penyuluhan

\begin{tabular}{lcccc}
\hline \multirow{2}{*}{ Kategori } & \multicolumn{2}{c}{ Sebelum } & \multicolumn{2}{c}{ Sesudah } \\
\cline { 2 - 5 } & $\mathrm{n}$ & $\%$ & $\mathrm{n}$ & $\%$ \\
\hline 1. Cukup & 36 & 63,16 & 9 & 15,78 \\
2. Baik & 12 & 21,05 & 25 & 43,85 \\
3. Sangat baik & 9 & 15,79 & 23 & 40,35 \\
\hline Total & 57 & 100 & 57 & 100 \\
\hline
\end{tabular}

Sumber: Pengabdian kepada masyarakat tahun 2019

Pengetahuan merupakan domain penting untuk membentuk suatu perilaku (overt behaviour). Tabel 2 diatas menunjukkan bahwa setelah pelaksanaan penyuluhan tentang stimulasi tumbuh kembang anak usia dibawah 2 tahun, diperoleh peningkatan pengetahuan peserta dengan kategori sangat baik sebesar 24,56\%, kategori baik sebesar 22,8\%, dan kategori cukup 43,38\%. Adanya peningkatan pengetahuan peserta terhadap pentingnya stimulasi tumbuh kembang pada periode emas anak setelah mendapat penyuluhan diharapkan dapat meningkatkan kesadaran peserta untuk memperhatikan tumbuh kembang anak pada masa periode emas sehingga anak dapat melalui proses tumbuh kembang dengan baik dan positif sehingga terbentuk anak yang sehat, cerdas dan berkarakter sebagai generasi penerus bangsa yang berkualitas.

Tabel 3. Perbedaan tingkat keterampilan peserta sebelum dan setelah mengikuti pelatihan

\begin{tabular}{|c|c|c|c|c|c|}
\hline \multirow{2}{*}{\multicolumn{2}{|c|}{ Kategori }} & \multicolumn{2}{|c|}{ Sebelum } & \multicolumn{2}{|c|}{ Sesudah } \\
\hline & & $\mathrm{n}$ & $\%$ & $\mathrm{n}$ & $\%$ \\
\hline 4. & Cukup & 32 & 66,6 & 9 & 18,7 \\
\hline 5. & Baik & 11 & 22,9 & 21 & 43,7 \\
\hline 6. & Sangat baik & 5 & 10,5 & 18 & 37,6 \\
\hline & Total & 48 & 100 & 48 & 100 \\
\hline
\end{tabular}

Sumber: Pengabdian kepada masyarakat tahun 2019

Berdasarkan tabel 3 diperoleh peningkatan keterampilan peserta pelatihan pada kategori sangat baik meningkat sebesar 27,1\%, kategori baik sebesar 20,8\% dan kategori cukup sebesar 47,9\%. Sehingga dapat disimpulkan bahwa pengetahuan dan keterampilan peserta meningkat karena pelatihan. Pelatihan pada kegiatan ini dilaksanakan untuk meningkatkan pengetahuan dan 
keterampilan peserta terkait cara melakukan stimulasi dan mendeteksi penyimpangan yang terjadi pada proses tumbuh kembang anak di masa periode emas yaitu 1000 hari pertama kehidupan. Metode pelatihan digunakan untuk menggugah awareness atau kesadaran peserta sehingga berpengaruh terhadap perubahan perilaku. Peserta pelatihan ini adalah kader kesehatan yang diharapkan mampu memberikan pendidikan kesehatan kepada masyarakat. Setelah terjadi peningkatan pengetahuan diharapkan tumbuhnya sikap kesadaran akan pentingnya Golden Age Period atau masa emas pertumbuhan, dan untuk kader kesehatan diharapkan dapat mengaplikasikan ilmu yang diterima dalam training (pelatihan) dalam kehidupan sehari-hari dan diharapkan dapat terjadi transfer knowledge (transfer ilmu pengetahuan) dari kader kesehatan terhadap masyarakat sekitar.

\section{Referensi}

Kemenkes. (2018a). Tumbuh Kembang Optimal Dengan Stimulasi, Deteksi Dan IntervensiDini Tumbuh Kembang (SDIDTK). http://kesga.kemkes.go.id/berita-lengkap.php?id=45

Kemenkes, K. (2018b). Tumbuh Kembang Optimal Dengan Stimulasi, Deteksi Dan Intervensi Dini Tumbuh Kembang (SDIDTK). http://kesga.kemkes.go.id/berita-lengkap.php?id=45

Patria, S. Y. (2017). Gizi Anak pada Masa Emas ( golden age ). http://fk.ugm.ac.id/wp content/uploads/2017/09/Gizi-Anak-Golden-Age.pdf

Profil Kesehatan Indonesia. (2016). Profil Kesehatan RI 2015. In Profil Kesehatan Indonesia Tahun 2015.

Soetjiningsih. (2014). Tumbuh Kembang Anak Edisi 2. ECG.

Sugeng, H. M., Tarigan, R., \& Sari, N. M. (2019). Gambaran Tumbuh Kembang Anak pada Periode Emas Usia 0-24 Bulan di Posyandu Wilayah Kecamatan Jatinangor. Jsk, 4(3), 96-101.

Uce, L. (2014). The Golden Age. Gizi Anak Pada Masa Emas (Golden Age), 25, 223-301. https://doi.org/10.1007/978-3-319-04840-6_5

Unicef. (2011). Unicef annual report 2011. https://www.unicef.org/nutrition/files/UNICEF_Annual_Report_2011_EN_060112.pdf

\section{Ucapan Terima Kasih}

Puji dan syukur penulis panjatkan kehadirat Tuhan yang Maha Kuasa yang melimpahkan karunia-Nya, sehingga kegiatan pengabdian kepada masyarakat ini dapat dilaksanakan. Dalam kesempatan ini penulis mengucapkan terima kasih kepada Ka. UPT Puskesmas Sipoholon, dokter, bidan desa, kader dan semua pihak yang terkait dalam pengabdian kepada masyarakat ini yang tidak dapat disebutkan satu persatu. Penulis menyadari masih banyak kekurangan dalam tulisan ini sehingga kami mengharapkan saran dan kritik untuk kesempurnaan penelitian ini. 